\title{
THE MONK (1796): A HISPANIST'S READING
}

\author{
Abigail Lee Six \\ Royal Holloway, University of London
}

\begin{abstract}
This article argues that the honour plays of seventeenth-century Spain have been overlooked as precursors to the Gothic. Reading Lewis's The Monk through this prism reveals that Spanish concept of honour plays sheds light upon the characterization of Ambrosio. Furthermore, the honour code gives rise to numerous areas of common ground with the Gothic, including the centrality of sexual secrets, imprisoned women, and a predilection for gore. Lewis's opportunities for access to this Spanish corpus are considered and finally, it is posited that the post-eighteenthcentury figure of the Gothic villain who is troubled and complex may be traceable, via The Monk, to the Spanish Golden Age.
\end{abstract}

Keywords: Matthew Lewis, The Monk, Spanish honour drama.

A variety of texts and authors have been cited as precursors to the Gothic mode, ranging from Shakespeare, cited by Horace Walpole in his preface to the second edition of The Castle of Otranto (1765, p. 10-11) to Perrault's tale "La Barbe Bleue," amongst other sources

\begin{tabular}{|l|l|l|l|l|}
\hline Ilha do Desterro & Florianópolis & n 62 & p. 025- 054 & jan/jun 2012 \\
\hline
\end{tabular}


(Hendershot, 1998, p. 26-27). ${ }^{1}$ However, few present-day Gothic scholars, if any, have studied the honour drama of the Spanish Golden $\mathrm{Age}^{2}$ with this precursor role in mind, despite the fact that some of the most prominent Gothic novels use Spain as a setting, including most of Matthew Lewis's The Monk and select portions of Charles Maturin's Melmoth the Wanderer (1820). ${ }^{3}$ More importantly, there are very striking thematic and atmospheric similarities between this Spanish dramatic tradition and the Gothic mode, notwithstanding significant differences between how they are to be interpreted. This article will explore these resonances with reference to The Monk so as to establish whether there are sufficient grounds to consider Spanish Golden Age honour drama as a new body of precursor texts to the Gothic mode.

We know how widely read Don Quixote was in the eighteenth century right across Europe including Britain, demonstrating awareness of Spanish Golden Age cultural production abroad ${ }^{4}$ and indeed, what might be termed the Quixote effect is easy to find in Gothic texts, including The Monk, which has references to the text itself (Lewis 6) and to several romances of knight errantry which are also mentioned in Don Quixote (Lewis 259). The premise of the found manuscript in a foreign language, including comments on the problems of translation, is used, amongst others, by Walpole (7). The idea of a protagonist obsessed by her or his reading to the point where $\mathrm{s} / \mathrm{he}$ imagines that the fantasy world of her/his books has entered humdrum everyday life is a Cervantine idea borrowed wholesale, not only by Charlotte Lennox, with The Female Quixote (1752) and other writers who published overt imitations and re-workings, but is put to specifically Gothic use by Jane Austen in Northanger Abbey (1817), with the romances of knight errantry substituted for Gothic ones besotting the protagonist; furthermore, Quixote's fantasized vision of the medieval world is echoed by many classic Gothic writers, who also tend to set their stories in that 
age and to portray the period as peopled with larger-than-life villains, supernatural occurrences, and damsels in distress.

However, when a Hispanist reads The Monk in particular, it is the honour plays of the Golden Age that spring to mind most readily, leading to the questions that this article will examine: whether and if so, how Matthew Lewis might have had any contact with classical Spanish drama; which elements of this genre prefigure Gothic features found in The Monk; where the two part company and the effect of those divergences; and finally, the extent to which the representation of Spain in this novel, particularly the Catholic Church, does or does not chime with Spanish literary production, on the one hand, and other Gothic texts on the other.

It is not known whether Matthew Lewis had read or seen any Spanish honour drama; his letters make no mention of plays of this kind, no visits to Spain are on record, and the curriculum of the school he attended (Westminster) did not include any modern languages at the time he was there. ${ }^{5}$ On the other hand, he is known to have spoken Spanish (Macdonald 65) and he was good friends since their days together at Christ Church, Oxford, with Henry Richard Fox, Lord Holland, the most prominent Hispanophile of his generation, who produced a monograph on leading Golden Age dramatist Félix Lope de Vega y Carpio (1562-1635), translated plays by Pedro Calderón de la Barca (1600-1681), another master of the genre, and had an extensive library of Spanish books at Holland House, where Lewis was a frequent visitor. ${ }^{6}$ In fact, Lope and Calderón are both mentioned in The Monk (though the latter is misspelt, appearing as "Calderona" (Lewis 199)). Thus, it remains possible that Lewis had read some Spanish drama; at the very least, he could have had conversations with Lord Holland in which the latter might have told him about the genre and some of the key plays in this tradition. ${ }^{7}$ Indeed, if The 
Monk can be taken as evidence, it would seem that the long-standing friendship between the two men has been underestimated to date, particularly with regard to its impact on Lewis's presentation of Spain and Catholicism in his fiction.

Holland's known political opposition to established religion ${ }^{8}$ should not be mistaken for anti-Catholicism; indeed, he advocated for Catholic rights in England and could not have been the lover and long-term visitor of Spain that he indisputably was, a country whose whole atmosphere and culture is and always has been inextricably bound up with its Catholic cultural heritage, unless he found that aspect of it tolerable at least and perhaps aesthetically pleasing and/ or emotionally appealing as well. ${ }^{9}$

It is worth noting, finally, with regard to this question of the likelihood of access to Spanish texts by Lewis, that in 1817, a review of the above-mentioned Lope de Vega monograph was published in the Quarterly Review, which includes commentary on Holland's observation that Horace Walpole might have taken the idea of the sighing portrait in The Castle of Otranto from Lope's epic poem entitled Jerusalén conquistada (1609) ["Jerusalem Conquered"]. ${ }^{10}$ This suggests that both the Spanish author and this particular work of his were well enough known in England to be thought to have possibly inspired someone like Walpole half a century before. Be that as it may, elements of The Monk bear such a resemblance to Spanish Golden Age works that some contact with them by Lewis, direct or indirect, and via Holland or not, seems a valid starting hypothesis.

It is therefore perhaps not coincidental that in the same poem, Lope's description of a rapist's feelings after committing his crime chimes strikingly with Matthew Lewis's. Lope is describing King Rodrigo's emotions after raping (or according to some versions, seducing and extracting consent from) Florinda. Lope says: 
Siguió a la injusta furia la tibieza

Apareciose el arrepentimiento

Que viene como sombra del pecado

Principios del castigo del culpado.

(Lope de Vega 133) 11

[The wrongful fury was followed by coolness

Repentance appeared

Which comes like sin's shadow

Initiating the punishment of the blameworthy. ${ }^{12}$

Though coincidence combined with psychological plausibility cannot be excluded, one can hardly fail to note how similar these emotions are to those of Lewis's protagonist, Ambrosio, both after possessing Matilda (which, incidentally, also lies in ambiguous terrain as far as the man's culpability is concerned) and, subsequently, Antonia. Following his rape of Matilda, "The burst of transport was past: Ambrosio's lust was satisfied; Pleasure fled, and Shame usurped her seat in his bosom." After Antonia, "The very excess of his former eagerness to possess Antonia now contributed to inspire him with disgust; and a secret impulse made him feel, how base and unmanly was the crime, which He had just committed" (Lewis 223 and 384, respectively; archaic capitalization as in edition used). Furthermore, the very idea of describing the feelings of a rapist/sexual predator just after he has committed his crime is something that this source and The Monk have in common. Even though Lewis himself admits to drawing upon the story of Santon Barsisa (Lewis 6), which recounts how this cave-dwelling saint, chaste for a hundred years, goes on to rape and murder a beautiful princess, his story and character are presented differently in several key respects: notably in the present 
context, no post-coital disgust or coolness towards his victim is described and his self-denial until this point is not explained in any way, so that he cannot be regarded - as Ambrosio can - as having had little if any choice in his life of self-denial to date. ${ }^{13}$

Be that as it may, Lope de Vega was, and still is, far better known for his honour plays than for his poetry, and here the social ruin of dishonour is recurrently compared with and deemed worse than death, which explains why the characters in plays and other works dealing with this topic are willing to kill and to die in order to defend or cleanse their honour. ${ }^{14}$ Moreover, the Spanish honour code inevitably generates paranoia since a man's fate (and in some circumstances, a woman's too) is in the hands of others and he must therefore devote his energies to attempting to control something which is by its nature beyond his control: not only the actual behaviour of the girls and women in his charge, but also the idle and perhaps malicious scandal-mongers in the street, the accidental giving of a false impression and such other fortuitous and luck-dependent factors as attend everyday life. ${ }^{15}$ This diverges sharply from English cultural tradition, which prizes a man's honour too, but attaches a different meaning to the concept and, above all, keeps it strictly within his own control. This, for example, is said on the subject in William Godwin's Caleb Williams, published just two years before The Monk: "I can only be dishonoured by perpetrating an unjust action. My honour is in my own keeping, beyond the reach of all mankind" (98). Indeed, the premise of that novel weighs against one another the importance of personal integrity-honour in the traditional English sense, personified in the eponymous protagonistand social reputation: honour in the Spanish sense, represented by Mr Falkland. ${ }^{16}$ It is noteworthy that even though Falkland succeeds in ruining Williams socially by unfairly blackening his name, the 
latter never loses his self-respect and inner dignity because he knows himself to be innocent, whereas Godwin portrays Falkland, with his elevated social standing and unblemished reputation, as the tortured soul, because he knows himself to be lacking in personal integrity and no amount of public respectability can compensate for that. The thrust of the narrative is implicitly to condemn Falkland for setting more store by his reputation than by personal morality, whereas in a Spanish context, Falkland's obsessive protection of his public standing could easily have made of him the tragic hero of the piece, especially since the murder he committed was of an evil man.

On the Spanish stage, not only are the characters expected to care about their social standing above all else, but also any threats to a man's honour are almost always connected with sexual behaviour, casting women as the repository of male honour. ${ }^{17}$ This is one key reason why Ambrosio's characterization feels very familiar to a Hispanist reader of the novel. Like a Spanish protagonist, Ambrosio worries little about his personal integrity, but is obsessed with maintaining his social standing of immaculate celibacy, virtue and piety. In the scene describing the aftermath of his first sexual experience with Matilda, breaking his vow of chastity, he tells her: "Should your sex be discovered, ${ }^{18}$ my honour, nay my life, must pay for the pleasure of a few moments" (Lewis 223). In other words, he is not primarily worried that God or even he himself knows he has sinned, but first expresses concern about the fact becoming known publicly. A little later and in the same vein, he dwells upon the consequences of losing Matilda: "Deprived of her, He would not easily find another Mistress, with whom He could indulge his passions so fully, and so safely" (Lewis 225; my italics). Similarly, when he later rapes Antonia, he tries to persuade her to stop resisting him by arguing: "Why reject pleasures so sweet, so rapturous? No one 
observes us: Our loves will be a secret to all the world" (III, 4, 382). And when she tries to escape, he rants: "What? That you may denounce me to the world? [...] You shall not from hence to tell Madrid that I am a Villain" (Lewis 385). However, the fact that a character like this appears in an English novel is crucial to how we read him: in the English literary context he is a hypocrite of the worst order and a Gothic villain par excellence, not only for the crimes he commits but also for his obsession with his public image relative to his cavalier attitude to morality. Had he appeared in a Spanish text, however, this might have been understood more sympathetically and his situation credited with greater complexity. Indeed, in play after play, characters who commit crimes to cleanse their honour are treated sympathetically by those who might have condemned and punished them. Pedro Crespo, for example, is pardoned by the King in Calderón's El alcalde de Zalamea (probably 1642) ["The Mayor of Zalamea"] and appointed mayor for life by him. A different King reaches a similar conclusion at the end of Lope's Fuenteovejuna (c.1612-14), pardoning the whole village for an honour murder. ${ }^{19}$

Not only is the notion of honour in the Spanish sense of public opinion an important area of common ground between Golden Age drama and The Monk, albeit inviting different interpretations in each case, but its presence on the seventeenth-century Spanish stage leads to certain linked motifs which prefigure their importance in the Gothic mode generally and Lewis's novel in particular. For example, it follows from the logic of a code which is predicated upon public knowledge, that secrecy is a mainstay of Spanish honour drama, just as it is in the Gothic, seen typically enough in The Monk with Ambrosio's attempts to cover up his crimes and indeed the Prioress's to do likewise with respect to Agnes. In both genres, too, 
the secrets around which the plot is built tend to be sexual, and the keeping of them generates innocent victims and suffering. Just as Antonia suffers and dies in order to protect the secret of Ambrosio's sexual enjoyment of her, so many Spanish heroines before her have paid with their freedom first and then their lives to keep a sexual misdemeanour (or the appearance of one) out of the public domain. The very name of Calderón's A secreto agravio, secreta venganza (1635) ["For a Secret Offence [to one's honour understood], a Secret Revenge"], for example, encapsulates this.

An important further corollary of the honour code, and the necessity it generates for men to control women's sexuality, is the attempt to keep them behind closed doors. As in the Gothic, houses are often represented metaphorically as prisons, a fact that is apparent, for example, from the title of another play by Calderón: Casa con dos puertas, mala es de guardar (1629) ["A House with Two Doors Is Hard to Guard"]. Lewis, as well as other eighteenth-century Gothic authors like Walpole and Radcliffe, also repeatedly utilize the motif of the imprisoned woman to powerful effect. ${ }^{20}$

The heroines of Golden Age honour plays respond to their enclosure in a variety of ways, but these can be divided into two main categories each of which prefigures a different Gothic pattern: there are the women who challenge it, perhaps by smuggling a man in, perhaps by escaping from the house, ${ }^{21}$ and there are the ones who are represented as virtuous, for whom the house serves as a refuge from would-be seducers. ${ }^{22}$ In the first case, where the woman either betrays or appears to betray her husband, he finds himself obliged to try to cleanse his honour and in play after play (as well as prose treatments of the theme), we find words to the effect that honour can only be washed clean by blood. This leads to many gory horror moments (whether described or enacted onstage) which strongly anticipate the predilection for spilt blood in the Gothic- 
often that of defenceless women too-an aspect of the mode which has in its turn fed into the contemporary sub-genre of the slasher film (Freeland 204). The Monk is no exception in this regard, whether in the Bleeding Nun episode, or the discovery of the phallically and mortally stabbed Antonia, the tortures of the Inquisition, or the slow and very painful death of Ambrosio. An example of the taste for gory horror on the Golden Age stage is in Calderón's El médico de su honra, when the barber-surgeon who has just been forced at knifepoint by the protagonist to bleed his wife, Doña Mencía, to death and then turned out into the street blindfolded, manages to denounce the crime to the King because, as he tells him:

Señor, que saqué bañadas

las manos en roja sangre,

y que fui por las paredes,

como quise arrimarme,

manchando todas las puertas,

por si pueden las señales

descubrir la casa.

(Act III, Scene 15; Calderón 1968: 222-23)

[Sir, when I left my hands were bathed in red blood, and as I groped my way as if clinging to the walls, I stained all the doors, in case the marks reveal the house.]

The mental picture conjured in the audience's imagination of the terrified barber blindly stumbling along with his bloody hands is surely worthy of any Gothic text.

Where the heroine of a Spanish honour play is virtuous and resists attempts to seduce her, a different Gothic motif can be 
prefigured, for now her would-be suitor in desperation may resort to supernatural means to win her, just as Lewis introduces the same methods (via Matilda) for Ambrosio to have his way with Antonia. This idea harks back to Fernando de Rojas's La Celestina (probably 1499) ${ }^{23}$ but is picked up in the Golden Age in Lope de Vega's $E l$ caballero de Olmedo, for example, where the services of a witch are employed to win the favours of the heroine. Another alternative appears when a protagonist learns black magic himself by selling his soul to the Devil, as in Calderón's El mágico prodigioso (1637) [“The Prodigious Magician"], this being one of the most popular plays for English translators (Paun de García and Larson 17).

The effect of enclosure upon the sanity and morale of the women in Spanish plays varies. Such variation may be attributable to the extent to which they endorse it because they want to preserve their reputation too, or they are trying to get round it; in the latter case, whether they are successful offers a further inflection; and their reasons may be presented as more or less excusable, depending on the plot and most of all on the chiefly tragic or comic thrust of the piece. Not all housebound heroines, in other words, are presented as suffering greatly, but some undoubtedly are and these prefigure the innumerable women in Gothic texts who suffer a similar fate. For example, in the above-quoted El médico de su honra, the heroine tries to call her servant Jacinta not long before she will be murdered, having just received warning of the fact from her husband:

¡Válgame Dios! ¡Jacinta, hola! ¿Qué es esto?

¿Nadie responde? ¡Otro temor funesto!

¿No hay alguna criada?

Mas ¡ay de mí!, la puerta está cerrada,

¿nadie en casa me escucha? 
Mucha es mi turbación, mi pena es mucha.

Destas ventanas son los hierros rejas, y en vano a nadie le diré mis quejas, que caen a unos jardines, donde apenas habrá quien oiga repetidas penas.

(Act III, Scene 9; Calderón 1968: 214)

[God help me! Jacinta, ho there! What is this? No-one answers? Another dreadful fear! Is there no maid here? But, alas! The door is locked; can no-one in the house hear me? I am greatly troubled, greatly pained. From these windows the bars are iron and in vain will I lament to anyone, for they overlook gardens where there is scarcely anyone to hear repeated troubles.]

This resonates with Agnes's pitiful description of her imprisonment: "I [...] endeavoured to open the door, but it resisted all my efforts. I stretched my voice to the extent of its compass, and shrieked for aid: I was remote from the hearing of every one" (Lewis 404).

Another type of paranormal element than witchcraft and soulselling is also found in a Golden Age honour play and prefigures Gothic usage of the same motif. This is the accomplishment of a prophetic saying which seals the fate of one or more characters and gives an air of inexorability to the whole, just as one has with the curse in Otranto hanging over Manfred, mentioned on the very first page of the text or the gypsy's prediction in the first chapter of The Monk (Lewis 38). This type of effect, whereby one knows from the outset that something dreadful will come to pass, but not how nor when nor in what circumstances, leads to an atmosphere of impending doom and inescapable suffering which makes a substantial contribution to the atmosphere typical of Gothic fiction but Lope uses the same technique in El caballero de Olmedo, the story-line of which plays 
towards the accomplishment of a ballad recounting the death of the title character. ${ }^{24}$ One of Calderón's most celebrated plays, La vida es sueño (1635) ["Life is a Dream"], also takes a prediction as its premise, this time an astrological one foretelling the ill-starred future of a newborn prince, which leads his father to try to prevent its realization by raising him chained in a tower, a contributory factor to his appalling behaviour when he is first freed, making it another Golden Age play with suggestive prefigurative features relative to The Monk.

With so many similarities, one would be forgiven for asking why these Spanish dramatic texts are not considered full-blown Gothics avant la lettre. However, notwithstanding the common ground, there are some important divergences, which together lead to a different overall impact. The divergence between England and Spain in the approach to honour has already been discussed. A further key factor is surely the fact that evil is not presented on the Spanish stage as the terrifyingly powerful force which it is in the Gothic mode. Wholly evil human characters comparable to the grandiose scale of the characterization of the traditional Gothic villain are relatively rare; some who do wrong are misguided and/or tricked, such as Cipriano who makes the pact with the Devil in El mágico prodigioso. Others who are exploitative and scornful of the peasantry, such as the Comendador [Governor] in Lope's Fuenteovejuna or the army Captain in Calderón's El alcalde de Zalamea, are treated as criminals rather than larger-than-life villains and such characters are punished for their crimes. It is true that many Gothic villains, including Ambrosio, receive punishment for their crimes too, but the damage they have done by then tends to be presented as irreparable: innocent people are dead, others' lives are in ruins. By contrast, the Spanish tradition offers a solution for at least some victims. Laurencia of Fuenteovejuna, despite having been raped by the Comendador, is 
still accepted by her former betrothed whilst Isabel of El alcalde de Zalamea, who has also been raped, willingly enters a convent, with an implication that this will provide the necessary consolation, bearing in mind that, in a Catholic culture, taking the veil is regarded as a virtuous and worthwhile life-choice. This is indeed presented by her father as his daughter's wise decision to take a husband who will pay no heed to her lost virginity. ${ }^{25}$ Besides, if, as we have seen, the honour code keeps girls and women behind closed doors whether they are single, married or nuns, the convent is scarcely a greater form of imprisonment than any other.

As for the men who kill women for honour's sake, they may be the forerunners of the Gothic villain type as far as their role in the plot is concerned, but there the resemblance ends for these are such tortured individuals that one feels almost as sorry for them as for their victims. They tend to be shown as trapped in a no-win situation due to circumstances beyond their control; ${ }^{26}$ Don Gutierre, the wifemurderer of El médico de su honra, for example, weeps and prays to God for a way out in a key soliloquy before he masters his emotions and decides to adopt the role of physician to cure his personified wounded honour. ${ }^{27}$ Thus, within the dramatic logic of the play, both he and Mencía are exonerated and it is fate that is implicitly blamed for ensnaring both of them.

Admittedly, one can criticize Don Gutierre and other men in Spanish honour plays for letting themselves be so enslaved by a strict interpretation of the honour code and one can point to characters in other plays who find creative ways to salvage their honour while sparing the lives of the innocent, ${ }^{28}$ but the fact remains that even protagonists like Don Gutierre retain some claim to victim status, due to the society-and their position in it-in which accident of birth has trapped them, their temperament, and a fateful sequence of events beyond their control. 
Entrapment is a Gothic predicament par excellence too, applying not only to physically trapped characters such as women in crypts, but to the psychological state of many who find themselves entangled in Gothic plots that seem to offer them no way out.

Indeed, these same three elements-accident of birth, temperament, and fate-are precisely the ones that make Lewis's monk such a troubling character and, arguably, a Gothic villain of a subtly different kind from many of those created by other eighteenthcentury authors. Indeed, to that extent he can be seen as a direct ancestor of later figures, such as Dr Frankenstein or Heathcliff in the nineteenth century or Anne Rice's vampires in the twentieth. Even though one cannot condone Ambrosio's behaviour and even though one's pity for his victims is greater by far, the author has managed to create a Gothic villain who is simultaneously a victim himself. And if the novel remains scandalous precisely because it shows how profoundly evil acts can have causes too diffuse and complex for them to be unproblematically dismissed simply as a sinful exercise of free will, then that too is something which this text-if not all Gothics-has in common with the Spanish honour drama of the Golden Age. Thus, the tortured, driven murderers of Calderón and Lope might have been an inspiration to Lewis in this regard, with knock-on effects in later centuries.

Where the Gothic Spain of writers like Lewis and Maturin also seems at first sight to diverge most from the one a Hispanist recognizes as reminiscent of Golden Age drama, is in the portrayal of Catholicism, the Church, and the clergy. Lope, Calderón and their contemporaries present a view that is generally respectful and devout, showing piety as a virtue, and some of the ills of their characters as attributable to insufficient adherence to Christian values. Few clerics are on the cast-lists of honour plays, but the non-clerical characters 
who are represented positively are usually shown or can safely be assumed to be good Catholics. Even though there may appear to be a contradiction between endorsing Church doctrine and at the same time washing one's honour with blood, this is downplayed, as characters who do so are not generally condemned for being unchristian, but rather the values that underpin the honour codechiefly sexual fidelity and female chastity-are implicitly equated with Christian virtue and piety. Pedro Crespo, the protagonist of El alcalde de Zalamea, for example, is positioned as a good Christian and one for whom honour and piety go hand in hand, when he declares:
Al Rey la hacienda y la vida
se ha de dar; pero el honor
es patrimonio del alma,
y el alma sólo es de Dios

$$
(\mathrm{I}, 873-6)
$$

[To the King must be given one's wealth and one's life; but honour is the property of the soul and the soul belongs only to God].

Similarly, in Lope's Fuenteovejuna, when the villagers go to murder the Comendador who has raped Laurencia, their battlecry articulates their collective self-image as patriots and good Christians for cleansing their village's honour, in implicit contrast to the Governor: "¡Viva el rey Fernando! / ¡Mueran malos cristianos y traidores!” (III, 231-2) [Long live King Ferdinand! Death to bad Christians and traitors!] The few corruptible clerics that do appear tend to be of low ecclesiastical rank-such as sacristans-their misdemeanours are generally rather harmless, and they are to be found more often in light comedy than serious honour drama. 
Furthermore, their antics do not call into question the foundations of the Church in Spain or suggest systemic failings within it. Thus, for example, in La guarda cuidadosa (1615) ["The Careful Guard"], one of Cervantes's entremeses [short interlude plays], we find an amorous sacristan, but as he has taken no vow of chastity, he appears merely as a figure of fun and even has the last laugh for he marries the woman in question at the end of the play.

This different slant regarding the Catholic Church on the Spanish stage can result in motifs which it has in common with the Gothic working to sharply divergent effects. An example of this is to be found in the dramatic use of soul-selling. El mágico prodigioso makes the Devil as convincing a reasoner as he will be in Lewis's text (bolstered in the latter by the persuasive and seductive powers of Matilda, his instrument). As in the traditional Gothic treatment, we find in Calderón's play the contract signed in blood and the trickery by which the soul seller does not even get what he thinks the Devil has promised in return for his soul. However, the demonic pact appears in the Spanish play, not as a terrifying demonstration of the power of evil, as it does in the Gothic generally and The Monk in particular, but as a means to a Christian end: the conversion of a non-Christian and the saving of a soul. ${ }^{29}$

However, before asking why some Gothic authors portray the Catholic Church as such a terrifying institution, significant divergences between Gothic texts need to be taken into account. Maturin portrays the Inquisition in Melmoth, for example, as a thoroughly corrupt institution. However, the matter is more complicated in The Monk, as we shall see, for there does seem to be textual evidence in Lewis's text for a more neutral or even cautiously sympathetic interpretation of the representation of the Spanish Church than one might make at first glance, particularly if one 
lumps it together with other Gothic classics. Such a different stance might reflect the impact on Lewis's views of his friendship with Lord Holland and/or some awareness of Spanish cultural production. Indeed, we note that Ambrosio had been abandoned on the doorstep of the Capuchins as a baby and that the monks had taken pity on him and raised him out of charity (Lewis 16-17). The Capuchins mentioned other than Ambrosio do not seem evil or depraved, nor is there any suggestion that any of them are not there of their own volition. Furthermore, for a desperate mother to leave her child for them to find presupposes that the Capuchins must have had a reputation for such acts of charity.

As for the Poor Clares, it is easy to forget that notwithstanding her mother's vow to force Agnes into the convent (Lewis 130-31), in the event-and in sharp contrast to how the same motif is used in Melmoth-she enters it voluntarily (due to a fateful sequence of events which has made her erroneously despair of a happy marriage) (Lewis 92-94). Moreover, had the Prioress been a different individual, the convent might have provided solace and refuge for her in the first instance, and honourable release when the time came for her to wish it. After all, such release is presented in the novel as normally achievable without recourse to desperate escape strategies, once again in sharp contrast to the presentation of the same issue in Melmoth. ${ }^{30}$ Furthermore, when Elvira describes the Prioress to Lorenzo in the strongly negative terms that turn out to be all too accurate, she makes no suggestion that such women are typically to be found running convents, but indicts her very much as an individual (Lewis 21819). Even when Agnes tries to dissuade Virginia from taking the veil and is described as having "painted in their true colours the numerous inconveniencies [sic] attached to a Convent", these are rather moderate and realistic, a far cry from the lurid colours one 
might have expected in a virulently anti-Catholic Gothic novel, and the worst features are directly related to the individual character of the Prioress: "the continued restraint, the low jealousies, the petty intrigues, the servile court and gross flattery expected by the Superior" (Lewis 396-97). Finally, even though the Prioress and her group of supporters (Violante, Camilla, Alix, and Mariana) are cruel and sadistic towards Agnes, others in the convent, led by St Ursula and supported by Bertha and Cornelia, disapprove of that treatment and try to help her (Lewis 351-55). St Ursula's eventual denunciation of the Prioress is extremely courageous and goes to show that Lewis's convent contains the same sort of mixture of good and bad, cowardly and brave people, as does the outside world. Indeed, in that outside world lives the loathsome Baroness Lindenberg, showing that the convent has no monopoly on nasty women in this text. Finally, the Spanish populace reacts to St Ursula's account of what has been going on with uncontrollable fury, evidence that they do not accept such behaviour as the Prioress's as typical or normal within a convent.

With respect to the Inquisition in particular, by the time Ambrosio finds himself in its hands, his evil deeds have left the reader with so little sympathy for him that his rationally understandable terror at the torture he undergoes seems more like cowardice and his mental anguish like just desserts. This, then, is not the black-and-white portrayal of a corrupt Inquisition unjustly condemning the innocent, such as is to be found in Radcliffe or Maturin, for example, but one which-albeit by brutal means-has finally stopped a murderer and rapist in his tracks. ${ }^{31}$

Nevertheless, there is undoubtedly a powerful if implicit critique in Lewis's novel of the celibacy required of those in Catholic holy orders. This derives from two sources. Firstly, the events which lead Agnes to such despair that she chooses to enter the Poor Clares are inextricably bound up with the Bleeding Nun, the ghost whose 
intervention foils Raymond's plot to elope with her. Lewis chooses not to include this revenant's back-story, the events that led her to her unquiet and vengeful existence after death. Given the way she reacts to Raymond, however, and how she blights his and Agnes's chance of happiness, which would have saved the latter from the convent, it seems reasonable to assume that her suffering has to do with unrequited love. Whatever the details, one can infer from her presence in The Monk that at least some nuns are tortured souls and that this is likely to have something to do with their vow of chastity. Secondly, were it not for Ambrosio's former celibacy, he would not have bottled up his sexual appetite so much and for so long that the ensuing explosion and the irresistible urge to satisfy his lust would wreak such havoc, for it could arguably have been channelled safely into marriage long since.

However, this would seem quite a self-contained area of Catholic doctrine and does not necessarily imply a wholesale attack on the Church. Perhaps, then, this combination of a critique of celibacy with an otherwise gentler treatment of Roman Catholicism relative to some of Lewis's contemporary producers of Gothic fiction can be linked with the influence of his friend, Lord Holland, and the latter's Hispanophilia. Perhaps he had read and borrowed some ideas from Lope or Calderón. Maybe too, he had read contemporary accounts such as that of the vicar Joseph Townsend's travels in Spain, which describes hospitable and tolerant clerics (164 and 386) and at least one abbess known for the "sprightly sallies of her wit" (381) rather than cruelty or megalomania.

In conclusion, reading The Monk from a Hispanist perspective leads to an argument that would separate Lewis's text from those of some of his contemporary Gothic writers in three key areas. Firstly, his portrayal of a southern European society is less virulently anti- 
Catholic, limiting itself to an indictment of celibacy. Secondly, a subtler critique within the text takes us straight back to the drama of the Golden Age: caring too much and too exclusively, from an Englishman's point of view, about one's reputation in society-honour in the Spanish sense-is a key underlying cause of the misery of the events narrated (even the Prioress's monstrous cruelty is attributed to her wish to enhance the social standing of her convent), just as it also is in Spanish honour plays. Finally and most importantly, if Lewis did take from those deeply troubled and troubling Spanish honour-murderers, who are simultaneously villains and victims, part of his characterization of Ambrosio, which would in turn feed into the creation of later giants of the Gothic such as Dr Frankenstein, then that Spanish dramatic tradition deserves to be recognized as a significant precursor to the development of the Gothic mode.

\section{Notes}

1. In referring to the Gothic as a mode, I follow Hendershot (1), who adopts the term 'to extend the boundaries of the transgressive Gothic from either a rigid periodization in the late eighteenth century or a rigid definition.' Indeed, in looking at elements of texts pre-dating Walpole and arguing for their relevance to Gothic scholarship, this article is predicated upon such definitional flexibility.

2. This term refers to the very many Spanish plays dating from the late sixteenth and the seventeenth centuries with plots that revolve around one or more protagonists' honour being called into question. The meaning of honour in the Spanish cultural context will be discussed below.

3. Typical of the disregard of Hispanic culture by Gothic scholars is the chronology provided in The Cambridge Companion to Gothic Fiction, which in other respects offers an excellent introduction to Gothic Studies. Running to nine pages (xvii-xxv), it mentions French and German literary and cinematic texts as well as Anglophone ones from both sides of the Atlantic, but the only reference to a Spanish one is 
the very last item, the film The Others, by the Spanish-Chilean director Alejandro Amenábar (2001), not that that fact is mentioned in the entry, despite other films listed all giving credit to their directors. Hogle's introduction to the volume, which from its title, 'Introduction: the Gothic in western culture' (1-20), might have been expected to encompass Hispanic culture, mentions only Shakespeare as a precursor, says nothing of Hispanic producers of Gothic texts post-Walpole, and includes just a passing mention of a Latin American readership for Gothic texts in a list of new types of consumers of the Gothic (Hogle 3 ). This is only one example; it would be echoed by many other surveys of the Gothic. See Lee Six 12-16 for a discussion of the reception and production of Gothic texts in Spain.

4. For more on Quixote in England, see Ardila ed. Noteworthy, in particular, beyond the Gothic but contemporaneous with it, is William Godwin's use in Caleb Williams (1794) of the idea of an obsession with reading romance to the extent that Williams admits that the texts "took possession of my soul; and the effects they produced, were frequently discernible in my external appearance and my health" (4). This novel also bears striking similarities to the picaresque genre, and, indeed, Mateo Alemán's Guzmán de Alfarache is mentioned in Godwin's text (259) (spelt Gusman d'Alfarache there) and used in a very Cervantine way, since the protagonist feels as though he is living a picaresque adventure himself just as Quixote feels he is creating a new romance of knight errantry. Williams reflects upon printed versions of his own story too (268-69), just as Quixote does in Part II of Cervantes's text. Godwin's novel will be discussed further below for the light it sheds on how different English attitudes to honour are from Spanish ones.

5. "Arithmetic, algebra, modern languages, modern history, are wholly excluded" from the curriculum at Westminster, retorts one anonymous commentator in 1831 ("A Latin Grammar" 71).

6. Macdonald documents the long-standing and close friendship between Lewis and Lord Holland, referring to the latter as Lewis's "College friend" (24). Peck concurs with other accounts in dating Lewis's friendship with Holland to their university days at Christ Church (49). For a discussion of Lord Holland's Hispanism, see Alberich 295-308. For details on the Lope monograph, see 301. See Paun de García and Larson 17-18 for more on Lord Holland's translations of Calderón. For discussion of the Spanish holdings of the library at Holland House, see 
Alberich 302. Peck dates Lewis's "introduction to the brilliant circle of Holland House" "presumably" to 1 November 1797 (50), which postdates publication of The Monk, but he bases this on the first mention of him in Lady Holland's journal, which does not preclude earlier visits to Lord Holland and the library that were not necessarily worthy of written mention from her point of view. Paun de García and Larson contains a wealth of other information about how Spanish drama found its way to England over the centuries.

7. It is worth noting in this regard that Holland marks Lope's El caballero de Olmedo (1641) ["The Knight of Olmedo"] and El castigo sin venganza (1631) ["Punishment without Revenge"] as plays he has read himself in the appendix to his monograph ([Fox] 254), for these are both texts which have much in common with Gothic thematics.

8. Holland's view was that "the state had no right to enforce monopolies in education or public life which were based on religious exclusions. It simply had no standing in such matters, and should be neutral in everything pertaining to religion" (Mitchell 106, but see also 58 and 105-22).

9. Mitchell asserts that in the Lope monograph, Holland criticizes the playwright's religious bigotry (220), but this claim was not borne out by my own reading of the work; on the contrary, I found it rather tolerant of this aspect of Lope's drama. For Holland's support for the Catholic cause in the English Parliament, see Alberich 298.

10. See Walpole $120 \mathrm{n}$. 26. The review is attributed to Robert Southey in this note, though it is unsigned in the Quarterly Review itself ([Southey] 30).

11. This is the page number given on the digitized text. It is on page 261 according to the electronic pagination.

12. This and all other English translations are mine.

13. After the rape, Santon Barsisa rails at the Devil for tempting him, rather than reflecting on his feelings for the princess.

14. For an explanation of how the honour code is presented on the Spanish stage in the Golden Age and the only indirect relationship it bore to real life in the period, see McKendrick 1984: 313-35 and 1974: 35-39 and 273.

15. In Lope de Vega's El castigo sin venganza, for example, the Duke whose honour is slighted discovers the fact through an anonymous letter 
handed to him by an ill-dressed and perturbed individual he does not know. Nothing further is revealed about this person, who may or may not be the writer of the letter he is delivering, but whose troubled state suggests he knows its content. This is just one example of the fear (wellfounded in this play) of what is known or believed about one in the street. Calderón's El pintor de su deshonra (c. 1648) [“The Painter of His Own Dishonour"] provides an example of a false impression being given, since the audience knows that the wife who will be murdered by her husband has endeavoured to remain faithful to him, but that is not how it looks to him nor to other key characters in the play. In the fortuitous category, one could cite Calderón's El médico de su honra ["The Physician of His Honour"] where the prince who had shown an interest in Doña Mencía before her marriage to Don Gutierre, happens to have a riding accident just outside their house, leading to his having to be brought in to recover and in that way, renewing their acquaintance. The play was probably first performed in 1629. For a discussion of this dating of it, see Cruickshank 11-12. The play will be discussed further below.

16. Martínez gives a clear account of the evolution of Spanish notions of honour, originating in medieval times and explains the increasing dominance of an understanding of it predicated upon public opinion over social rank and chivalric values.

17. Although this is expressed one way or another in countless plays, the Duke in El castigo sin venganza encapsulates this particularly explicitly when he laments:

¡Ay, honor, fiero enemigo!

¿Quién fue el primero que dio

tu ley al mundo, y que fuese

mujer quien en sí tuviese

tu valor, y el hombre no? (III, 2811-15)

[Alas, honour, fierce enemy! Who was the first to give your law to the world and to make it woman and not man who would be the measure of your value?]

18. This refers to the fact that Matilda has gained access to Ambrosio by passing for a boy.

19. For a discussion of the date of Fuenteovejuna, see for example Smith Mitchell's introduction to the play (Lope de Vega 1966: 6). For that of $E l$ 
alcalde de Zalamea see for example Dunn's introduction (Calderón 1966: 7). Sympathy for honour crimes did not die out in Spain at the end of the Golden Age. For example, Emilia Pardo Bazán's short story, "Delincuente honrado" (1897) ["Honourable Delinquent"], has a sympathetically portrayed priest recounting the story of a murderer whose confession he heard just prior to his execution. Of all the criminals he has confessed, the priest states that this is the one for whom he had the most pity, yet the story turns out to be that the man murdered his completely innocent seventeenyear-old daughter, because she resembled too closely his wife, who had run away dishonourably and ruined his social reputation (Pardo Bazán 95-99).

20. This continues to have currency up to the present day. Indeed, Modleski asserts with reference to contemporary American pulp Gothics, that extreme situations of female imprisonment in dungeons, crypts, and such like are "concerned with [...] driving home to women the importance of coping with enforced confinement and the paranoid fears it generates" (20).

21. One example of a woman who escapes from her house in disguise is Doña Ángela in Calderón's La dama duende (1629) [“The Phantom Lady"]. An example of one who smuggles a man in is Doña Lorenza in Cervantes's El Viejo celoso (1615) [“The Jealous Old Man”].

22. Justina in Calderón’s El mágico prodigioso (1637) [“The Prodigious Magician"] is an example of a woman for whom her father's house serves as a refuge from would-be seducers.

23. For a discussion of the likely date of the work see Centro Virtual Cervantes <http://cvc.cervantes.es/obref/fortuna/expo/literatura/lite0228.htm>

24. According to Macdonald's preface to the play (Lope de Vega 1934: v), "the audience for whom it [the play] was written knew its tragic ending from the outset, for everyone was familiar with the popular ballad [...] on which the play is based." The key lines of the ballad, as they are sung in the play, are as follows:

Que de noche le mataron

al caballero,

la gala de Medina,

la flor de Olmedo. [...]

Sombras le avisaron

que no saliese,

y le aconsejaron 
que no se fuese,

el caballero,

la gala de Medina,

la flor de Olmedo.

(Act III, lines 2371-4 and 2383-9; Lope de Vega 1934: 93)

[For by night they killed him, the knight, the pride of Medina, the flower of Olmedo. Shadows warned him not to go out and they warned him not to go away, the knight, the pride of Medina, the flower of Olmedo.] In Lope's play, the title character has indeed been warned by a ghostly shadow before the point when the ballad is sung, so the audience would have recognized the beginning of the enactment of the ballad before they heard it chanted and therefore could see the murder approaching. The use of the simple past tense in the ballad further underlines the eerie inexorability of the knight's fate, for he seems to be helplessly living out something already in the past and hence unchangeable.

25. Un convento tiene ya

elegido y tiene esposo

que no mira en calidad.

(Act III, lines 956-8, Calderón 1966: 121).

[She already has a convent chosen and she has a husband who pays no heed to status.] The language used is indirect; Isabel's status as a nonvirgin is called her "calidad" [literally "quality"], with the advantage that it simultaneously alludes to her class status as a commoner, relative to her rapist with his higher status as an army officer. Thus, her "husband", Jesus Christ, will love her despite her commoner class as well as her lost virginity.

26. Don Gutierre did not know when he married Doña Mencía that she had been the object of the affections of none other than the King's son (without letting herself be seduced), that this prince had gone away and that then her father had married her off to him, Gutierre. It is only now when the prince unexpectedly returns, has a riding accident outside their house and is brought in to recover, that the old flame is rekindled. Still, she does not succumb to temptation, but an unfortunate sequence of events gives her husband the impression that she may be an adulteress.

27. Bien podéis, ojos, llorar:

no lo dejéis de verguënza. 
[...]

Pero vengamos al caso, quizá hallaremos respuesta.

$¡ O h$, ruego a Dios que la haya!

$¡ O h$, plegue a Dios que la tenga!

(Act II, Scene 16; Calderón 1968: 184-85)

[Well may you weep, eyes : do not hold back for shame. But let us come to the point; perhaps we shall find an answer. Oh please God there will be one! Oh please God He will have one!]

28. For example, Isabel's father in El alcalde de Zalamea transcends the normal expectations of the honour code, which his son wants to implement in full by murdering her. As mayor of the town, he imprisons his son, has the criminal executed ignobly with the garrotte, which is beyond his jurisdiction, and lets his daughter retire to a convent.

29. The Devil's victim, Cipriano, is living in Antioch, at a time when Christians were a persecuted minority there. The reason the Devil defaults on the deal is that Justina, the woman he undertook to bring to Cipriano, is Christian and her prayers protect her from the Devil's attempts to spirit her away to him. As a result the Devil tries to fob Cipriano off with a look-alike effigy which is, however, revealed to be a skeleton when its clothes are removed (perhaps, incidentally, prefiguring the Bleeding Nun in The Monk). As a result, Cipriano discovers the truth, converts to Christianity and is willingly martyred with his beloved Justina, safe in the knowledge that God's power and mercy are infinite and in return for his conversion, He will override the demonic pact and grant him a place in heaven alongside her.

30. A papal bull authorizing Agnes's release is obtained without excessive difficulty (Lewis 209).

31. Canuel argues subtly and persuasively that writers like Radcliffe present Catholicism and monasticism 'to expose [...] a terrifying logic of confessional government and then to assume [...] a more tolerant relation to religious belief' (56). Nevertheless, he constructs his argument to counter the more prevalent face-value interpretations of "the Gothic novel's shopworn images of clerical abuse - the forced confessions and tortures of the Inquisition, the confinements and seductions in convent $s$ and monasteries" (55). 


\section{References}

"A Latin Grammar, for the Use of Westminster School. London: 1830." The Edinburgh Review, or Critical Journal 99 (March 1831): 64-82.

Alberich, José. "Un hispanista temprano: Lord Holland." Revista de Literatura 16 (Oct.-Dec. 1955): 295-308.

Anonymous. 'The History of Santon Barsisa', in Alexander Chalmers, ed. The British Essayists; with Prefaces, Historical and Biographical. London: J. Johnson et al., 1807. Web. 20 April 2012. <http://books.google.co.uk/ books>

Ardila, J.A.G., ed. The Cervantean Heritage: Reception and Influence of Cervantes in Britain. Oxford: Legenda, 2009.

Calderón de la Barca, Pedro. El alcalde de Zalamea. Ed. Peter N. Dunn. Oxford: Pergamon, 1966.

Calderón de la Barca, Pedro. El pintor de su deshonra. Web. 23 April 2012. $<$ http://www.quedelibros.com/libro/5800/El-Pintor-De-Su-Deshonra. html>

Calderón de la Barca, Pedro. La vida es sueño. Ed. Albert E. Sloman. Manchester: Manchester University Press, 1961.

Calderón de la Barca, Pedro. No hay burlas con el amor; El médico de su honra. Madrid: Espasa-Calpe, 1968.

Canuel, Mark. Religion, Toleration, and British Writing, 1790-1830. Cambridge: Cambridge University Press, 2002.

Centro Virtual Cervantes. Web. 9 Feb. $2012<$ http://cvc.cervantes.es/obref/ fortuna/-expo/literatura/lite0228.htm $>$

Cervantes, Miguel de. Teatro completo. Ed. Agustín Blánquez. 2 vols. Barcelona: Editorial Iberia, n.d.

Cruickshank, William. "Introducción biográfica y crítica." Pedro Calderón de la Barca. El médico de su honra. Madrid: Castalia, 1989: 7-60. Print. [Fox], Henry Richard, Lord Holland. Some Account of the Life and Writings of Lope Félix de Vega Carpio. London: Longman, Hurst Rees, and Orme, 1806. Web. 9 Feb. 2012 <http://www.ebooksread.com/ authors-eng/henry-richard-vassall-holland/some-account-of-the-life- 
and-writings-of-lope-felix-de-vega-carpio-ala/1-some-account-of-thelife-and-writings-of-lope-felix-de-vega-carpio-ala.shtml>.

Freeland, Cynthia A. “The Slasher's Blood Lust.” Dark Thoughts: Philosophic Reflections on Cinematic Horror. Eds Steven Jay Schneider and Daniel Shaw. Lanham, MD: Scarecrow, 2003: 198-211.

Godwin, William. Caleb Williams. Ed. David McCracken. Oxford: Oxford University Press, 1982.

Hendershot, Cyndy. The Animal Within: Masculinity and the Gothic. Ann Arbor: University of Michigan Press, 1998.

Hogle, Jerrold E., ed. The Cambridge Companion to the Gothic. Cambridge: Cambridge University Press, 2002.

Lee Six, Abigail. Gothic Terrors: Incarceration, Duplication, and Bloodlust in Spanish Narrative. Lewisburg: Bucknell University Press, 2010.

Lewis, Matthew. The Monk. Ed. Howard Anderson. Oxford: Oxford University Press, 2008.

Lope de Vega. El caballero de Olmedo. Ed. I. I. Macdonald. Cambridge: Cambridge University Press, 1934. 1966.

. El castigo sin venganza. Ed. C. A. Jones. Oxford: Pergamon Press,

. Fuenteovejuna. Ed. William Smith Mitchell. London: G. Bell, 1966. . Jerusalén conquistada. Web. 9 Feb. $2012<$ http://books.google.co.uk/ books/reader $>$.

Macdonald, D.L. Monk Lewis: A Critical Biography. Toronto: University of Toronto Press, 2000.

Martínez, María Victoria. 'A vueltas con la honra y el honor: evolución en la concepción de la honra y el honor en las sociedades castellanas desde el medioevo al siglo XVII.' Revista Borradores, 8-9 (2008). Web. 20 April 2012 < http://www.unrc.edu.ar/publicar/borradores/Vol8-9/pdf>

McKendrick, Melveena. "Honour/vengeance in the Spanish 'Comedia': a Case of Mimetic Transference?” Modern Language Review 79 (1984): 313-35. 
. Women and Society in the Spanish Drama of the Golden Age: A Study of the "Mujer Varonil". Cambridge: Cambridge University Press, 1974.

Mitchell, Leslie. Holland House. London: Duckworth, 1980. Print.

Modleski, Tania. Loving with a Vengeance: Mass-Produced Fantasies for Women. New York: Methuen, 1984.

Pardo Bazán, Emilia. "Delincuente honrado." Cuentos de amor. Barcelona: e-litterae, 2009: 95-99.

Paun de García, Susan and Donald R. Larson, eds. The Comedia in English: Translation and Performance. Woodbridge: Tamesis, 2008.

Peck, Louis F. A Life of Matthew G. Lewis. Cambridge, MA: Harvard University Press, 1961.

[Southey, Robert.] "Some Account of the Lives and Writings of Lope Felix [sic] de Vega Carpio, and Guillen [sic] de Castro. By Henry Richard Lord Holland. 2 vols. London 1817." Quarterly Review 18:35 (Oct. 1817): 1-46.

Townsend, Joseph. A Journey Through Spain in the Years 1786 and 1787. Web. 9 February $2012<$ http://books.google.co.uk/books $>$.

Walpole, Horace. The Castle of Otranto: A Gothic Story. Ed. W. S. Lewis. Oxford: Oxford University Press, 2008.

[Received in 10/02/2011. Approved in 16/04/2012] 